\title{
Implementasi Jenis Kemasan Untuk Memperpanjang Umur Simpan Sayuran Pakcoy
}

\author{
Waryat $^{1}$ dan Yosi Handayani ${ }^{2}$ \\ ${ }^{1}$ Peneliti pada Pusat Penelitian dan Pengembangan Hortikultura \\ ${ }^{2}$ Peneliti Balai Pengkajian Teknologi Pertanian (BPTP) Jakarta \\ Email : waryat21@yahoo.com
}

\begin{abstract}
ABSTRAK
Komoditas hortikultura seperti sayuran merupakan produk hidup yang masih aktif melakukan aktifitas metabolismenya setelah dipanen. Hal tersebut dicirikan dengan adanya proses respirasi yang masih berjalan seperti halnya sebelum produk tersebut dipanen. Tujuan kajian ini adalah untuk mengetahui pengaruh jenis kemasan terhadap karakteristik dan umur simpan sayuran pakcoy yang disimpan pada suhu dingi. . Bahan yang digunakan dalam kajian ini adalah sayuran pakcoy, plastik PP, plastik PE, kertas koran dan plastik wraping. Sayuran pakcoy yang telah dipanen dimasukan kedalam empat jenis kemasan lalu disimpan pada suhu dingin. Pengamatan dilakukan setiap hari selama tujuh hari. Variabel yang diamatl antara lain kadar air, susut bobot, TPC dan Logam Berat (Pb dan $\mathrm{Hg}$ ). Rancaangan percobaan yang digunakan adalah rancangan acak lengkap. Hasil pengamatan menunjukkan bahwa sayuran pakcoy yang telah disimpan selama tujuh hari pada suhu dingin menggunakan PP mempunyai susut bobot terendah yaitu 5,84\%, sedangkan nilai kadar air $(93,65 \%)$, dan TPC $\left(6,4 \times 10^{5} \mathrm{cfu} / \mathrm{g}\right)$ terbaik pada sayuran pakcoy yang disimpan pada suhu dingin menggunakan PP. Sayuran pakcoy masih memiliki kaarakteristik yang baik seteleh disimpan selama 7 hari pada suhu dingin dan dikemas dengan plastik PP.
\end{abstract}

Kata kunci : Suhu, Jenis kemasan, Pakcoy, Karakteristik

\begin{abstract}
Horticultural commodities such as vegetables are living products that are still actively carrying out their metabolic activities after being harvested. This is characterized by the respiration process that is still running as before the product is harvested. The purpose of this study is to determine the effect of temperature and types of packaging on the characteristics of pakcoy vegetable. The materials used in this study are packcoy vegetable, PP plastic, PE plastic, newspaper and wraping plastic. Pakcoy vegetables that have been harvested are put into four types of packages and then stored at room temperature and cold temperature. Observations were made every day for seven days. Variables observed include water content, weight loss, percent damage and heavy metal ( $\mathrm{Pb}$ and $\mathrm{Hg}$ ). The design of the experiment used was factorial design. The observations showed that pakcoy vegetables that had been stored for seven days in cold temperatures using PP had the lowest shrinkage of 5.84\%, while the value of water content $(93.65 \%)$, and TPC $\left(6.4 \times 10^{5} \mathrm{cfu} / \mathrm{g}\right)$ best in pakcoy vegetables stored in cold temperatures using PP. Pakcoy vegetables still have good characteristics after being stored for 7 days in cold temperatures and packed with PP plastic.
\end{abstract}

Keywords: Temperature, Type of packaging, Pakcoy, Characteristics

http://ejournal.urindo.ac.id/index.php/pertanian

Article History :

Sumbitted 09 Juni 2020, Accepted 29 Juni 2020, Published 30 Juni 2020 


\section{PENDAHULUAN}

Pakcoy (Brassica juncea L.) adalah salah satu tanaman hortikultura yang mempunyai nilai komersial dan prospek yang cukup baik. Pakcoy merupakan tanaman semusim yang berdaun lonjong, haus, berbulu dan tidak berkrop. Setiap $100 \mathrm{~g}$ pakcoy mengandung 2,3 g protein, 0,3 g lemak, 4 g karbohidrat, 220 mg Ca, 38 mg $P, 2,9 \mathrm{mg} \mathrm{Fe}, 1,94 \mathrm{mg}$ vitamin $\mathrm{A}, 0,09$ mg vitamin B dan $102 \mathrm{mg}$ vitamin C [1]. Pakcoy kaya akan vitamin A, B, C, E dan K yang dibutuhkan oleh tubuh dan juga memiliki komponen kimia penghambat kanker [2].

Sayuran seperti pakcoy merupakan komoditas yang mudah mengalami kemunduran mutu atau kerusakan (perishable) yang menyebabkan masa simpannya tidak tahan lama (2-4 hari). Kerusakan dapat terjadi karena faktor fisiologis, fisik, kimia, parasitik maupun mikrobiologis. Kerusakan hasil tanaman sayuran masih cukup tinggi, akibat dari kerusakan tersebut tentu akan menimbulkan dampak kerugian ekonomi [3]. Tingkat kehilangan pada produk hortikultura, dalam hal kualitas dan kuantitas antara panen sampai ke konsumen berkisar $20-50 \%$ di negara berkembang dan 5-25\% di negara maju [4]. Di Indonesia, kehilangan pasca panen produk sayuran rata-rata mencapai 2540\%. Kader (2002) lebih lanjut menyatakan bahwa produsen dan pedagang untuk mengurangi kehilangan hasil harus 1) mengetahui faktor biologi dan lingkungan yang mengakibatkan penurunan mutu dan 2) menggunakan teknik pasca panen yang dapat menjaga mutu.

Komoditas hortikultura khususnya sayuran merupakan produk hidup yang masih aktif melakukan aktifitas metabolismenya setelah dipanen. Hal ini dicirikan dengan adanya proses respirasi yang masih berjalan seperti halnya sebelum produk tersebut dipanen. Keragaman akan laju respirasi pasca panennya sering dijadikan sebagai indikator tingkat laju kemunduran dari produk tersebut. Semakin tinggi tingkat laju respirasinya maka semakin cepat laju kemunduran dan semakin cepat kematian yang terjadi. Sayuran dan buah mempunyai kadar air yang cukup tinggi (55 - 85 \%) pada saat panen. Selain masih mengalami proses respirasi, terutama sayuran akan mengalami proses kelayuan. Sifat fisiologis ini menyebabkan sayuran memiliki tingkat kerusakan yang dapat mencapai $40 \%$. Proses metabolism sayuran setelah panen khususnya respirasi tidak bisa dihentikan tetapi proses tersebut dapat dikurangi. Salah satu cara yang dapat mengurangi atau menghambat proses respirasi sayuran adalah penyimpanan suhu rendah dan penggunaan kemasan yang tepat. Penggunaan ruang pendingin cocok untuk 
penyimpanan cabai karena dapat mempertahankan kesegaran produk untuk waktu yang lebih lama [5]. Kondisi optimum penyimpanan cabai merah segar berada di antara $5^{\circ} \mathrm{C}$ sampai $10^{\circ} \mathrm{C}$ dengan kelembaban relatif 95\% [6].

Pemakaian kemasan plastik dan penyimpanan pada suhu rendah, menjadi solusi yang dapat dipilih untuk mempertahankan mutu produk $[7,8,9]$. Tujuan penyimpanan suhu rendah adalah untuk memperpanjang masa kesegaran sayuran guna menjaga keberlanjutan pasokan, menstabilkan harga dan mempertahankan mutu [10]. Kemasan plastik dapat menyebabkan adanya perubahan kondisi udara lingkungan atau modifikasi atmosfer. Konsentrasi CO2 akan meningkat dan $\mathrm{O}_{2}$ menurun akibat interaksi dari respirasi komoditi yang dikemas dan permeabilitas bahan kemasan terhadap kedua gas tersebut. Penggunaaan film plastik sebagai bahan kemasan sayuran yang mudah rusak akan dapat memperpanjang daya simpannya serta menghambat penurunan susut bobot, meningkatkan citra produk, menghindari kerusakan saat pengangkutan, dan sebagai alat promosi. Plastik HDPE mempunyai kemampuan yang lebih baik dalam mengurangi penurunan susut bobot dan mempertahankan warna sayuran lobak selama penyimpanan [11]. Pengemasan buah tomat dalam kantong polietilen (PE) berlubang menghasilkan massa penyimpanan lebih lama dengan kualitas yang lebih baik Metode pengemasan di iklim tropis seperti Indonesia harus dikombinasikan dengan penyimpanan dingin. Suhu rendah mempunyai pengaruh besar terhadap atmosfer di dalam kemasan. Suhu rendah dapat mengendalikan pertumbuhan bakteri dan jamur dan memperlambat metabolis komoditi yang dikemas. Penyimpanan produk pada suhu rendah akan mengurangi laju pertumbuha mikrobiologi dan perubahan kimia pada produk [12].

Prinsip penyimpanan pada suhu rendah atau pendinginan menyatakan bahwa pada setiap penurunan suhu 8 으, kecepatan reaksi metabolisme berkurang setengahnya. Penyimpanan buah anggur pada suhu dingin yang stabil dapat memperpanjang daya simpan buah dilihat dari segi penurunan bobot atau kadar air [13]. Kehilangan air sebanyak $2-6 \%$ dapat menyebabkan penurunan kualitas. Perlakuan suhu penyimpanan dan pengemasan (dikemas dan tidak dikemas) memberikan pengaruh yang singnifikan terhadap kesegaran brokoli yang berupa kadar $\mathrm{CO}_{2}$, kadar air, warna dan vitamin $\mathrm{C}$ [4]. Pengemasan disertai dengan temperatur yang tepat bisa mempertahankan kualitas selada sehingga kandungan vitamin maupun kadar air didalamnya dapat terjaga dan juga 


\section{Jurnal IImiah Respati}

terhindar dari bakteri sehingga tidak terjadi kebusukan pada selada. Berdasarkan latar belakang diatas, untuk mengetahui kondisi optimum yang diperlukan dalam penyimpanan sayuran pakcoy sehingga dapat mempertahankan mutu dan meningkatkan daya simpannya, maka perlu dilakukan kajian tentang kemasan yang sesuai untuk sayuran pakcoy. Tujuan kajian ini adalah untuk mengetahui pengaruh jenis kemasan terhadap karakteristik dan umur simpan sayuran pakcoy yang disimpan pada suhu dingin.

\section{METODE}

Waktu dan Tempat Penelitian

Kajian ini dilaksanakan pada bulan Mei sampai dengan September 2019 di Balai Pengkajian Teknologi Pertanian (BPTP) Jakarta dan Balai Besar Pasca Panen Hasil Pertanian, Bogor.

\section{Bahan dan Alat}

Bahan yang digunakan dalam kajian ini antara lain pakcoy, plastik PP, plastik PE, wraping plastik, dan kertas koran/kertas buram serta bahan-bahan kimia yang digunakan untuk pengujian, sedangkan alat yang digunakan antara lain timbangan, chromameter dan kulkas yang digunakan untuk penyimpanan suhu dingi.

\section{Tahapan Pengkajian}

Pakcoy setelah dipanen dibersihkan lalu dikemas menggunakan empat jenis kemasan yaitu plastik PP berlubang, plastik PE berlubang, wraping plastik, dan kertas koran/kertas buram. Setelah dikemas, pakcoy disimpan pada suhu dingin $\left(6-9^{\circ} \mathrm{C}\right.$ dan $\left.\mathrm{RH} \quad 10 \%\right)$. Pengamatan karakteristik pakcoy dilakukan setiap hari yaitu hari ke-0 sampai hari ke-7. Vaeiabel yang diamati antara lain : susut bobot, kadar air, total mikroba (TPC) dan kandungan logam berat ( $\mathrm{Pb}$ dan $\mathrm{Hg})$.

\section{Rancangan Pengkajian}

Rancangan percobaan yang digunakan adalah rancangan acak lengkap (RAL). Sebagai faktor utama adalah jenis kemasan (PP, PE, wraping plastik, dan kertas koran/kertas buram).

\section{HASIL DAN PEMBAHASAN}

Kondisi penyimpann sangat berpengaruh terhadap masa simpan sayuran pakcoy. Pakcoy yang telah dipanen masih melangsungkan proses metabolisme. Salah satu cara untuk menghambat laju metabolisme pakcoy adalah penyimpanan pada suhu rendah. Suhu adalah faktor sangat penting yang paling berpengaruh terhadap laju kemunduran dari komoditi pascapanen. Setiap peningkatan $10^{\circ} \mathrm{C}$ laju kemunduran meningkat dua sampai tiga kali. Komoditi yang dihadapkan pada suhu yang tidak sesuai dengan suhu penyimpanan optimal, menyebabkan terjadinya berbagai kerusakan fisiologis. 
Suhu juga berpengaruh terhadap peningkatan produksi etilen, penurunan $\mathrm{O}_{2}$ dan peningkatan $\mathrm{CO}_{2}$ yang berakibat tidak baik terhadap komoditi. Perkecambahan spora dan laju pertumbuhan mikroorganisme lainnya sangat dipengaruhi oleh suhu. Laju respirasi pada suhu $0^{\circ} \mathrm{C}$ sebesar $21.93 \mathrm{ml} / \mathrm{kg}$.jam dan $22.93 \mathrm{ml} / \mathrm{kg}$.jam berturut-turut untuk $\mathrm{O}_{2}$ dan $\mathrm{CO}_{2}$. Sementara pada suhu yang lebih tinggi $\left(27^{\circ} \mathrm{C}\right)$, berkisar antara 190.99 $\mathrm{ml} / \mathrm{kg}$.jam untuk $\mathrm{O}_{2}$ serta $198.17 \mathrm{ml} / \mathrm{kg}$.jam untuk $\mathrm{CO}_{2}$. Hal tersebut membuktikan bahwa laju respirasi dipengaruhi oleh suhu penyimpanan, dimana suhu rendah secara signifikan dapat menurunkan nilai laju respirasi [15]. Sayuran segar dapat terjual dalam 7- 8 hari setelah disimpan pada suhu rendah [16].

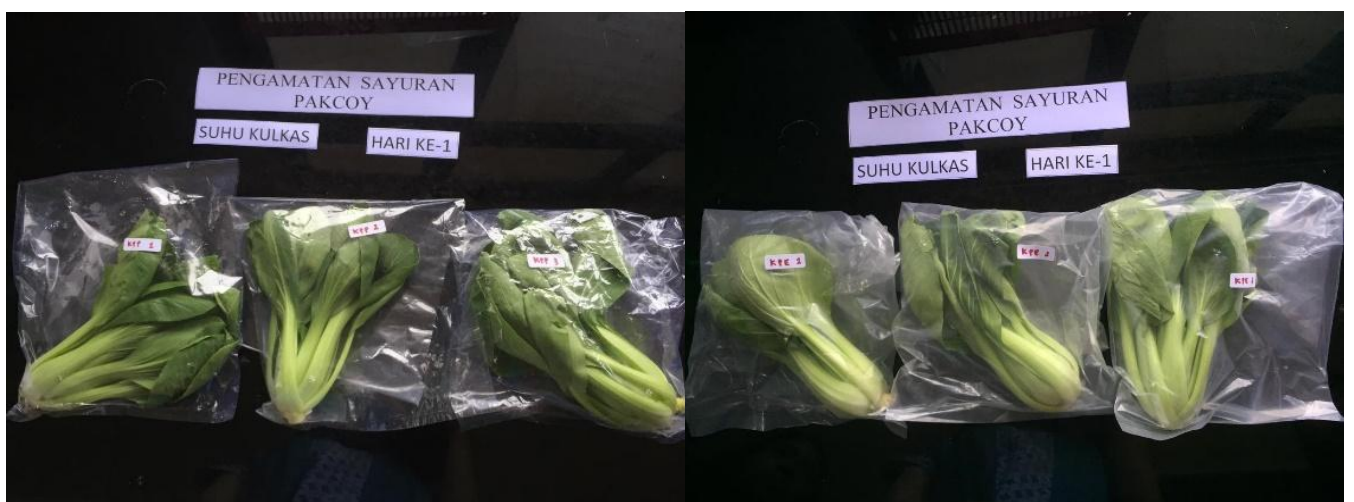

A
B

Gambar 1. Pakcoy dikemas dengan plastik A) PP dan B) PE

Pakcoy setelah dipanen lalu dipilih yang seragam ukurannya. Kemudian disiapkan kemasan plastik jenis PP PE, wrapping dan kertas Koran (Gambar 1). Sayuran pakcoy kemudian dimasukkan ke dalam masing-masing kemasan dan dikemas dengan hand sealer. Kemudian kemasan yang berisi sayuran pakcoy disimpan pada suhu suhu dingin. Penyimpanan dalam suhu dingin dilakukan di ruang pendingin. Pengamatan terhadap sample dilakukan pada hari ke-0 dan hari ke-7. Pengamatan dilakukan terhadap perubahan berat, kadar air, Total Plate Count (TPC) dan logam berat ( $\mathrm{Pb}$ dan $\mathrm{Hg}$ ).

\section{Susut Bobot}

Susut bobot merupakan salah satu variabel indicator penurunan mutu produk pertanian. Perubahan susut bobot diamati bertujuan untuk mengetahui perubahan susut bobot sayuran pakcoy selama penyimpanan. Pada semua perlakuan jenis kemasan terjadi penurunan susut bobot pakcoy dari bobot awal dan laju penurunan lebih cepat terjadi pada penyimpanan kontrol (tanpa kemasan). Penurunan bobot 


\section{Jurnal IImiah Respati}

pakcoy selama penyimpanan disebabkan oleh pakcoy kehilangan air sehingga berdampak pada penurunan bobot. Susut pascapanen karena proses fisiologis akibat terjadinya proses transpirasi, respirasi dan reaksi-reaksi lain karena sayuran pakcoy memiliki kandungan air $80 \%-90 \%$ dari bobot yang sebagian dapat hilang karena proses fisiologi tersebut, kehilangan air akan lebih cepat pada suhu tinggi dibandingkan suhu rendah [17].

Hasil analisis data perubahan berat (susut bobot) sayuran pakcoy pada kondisi suhu dingin, dapat diketahui permeabilitas pada kemasan plastik. Pada suhu dingin, permeabilitas pada plastik PP tidak berbeda nyata dengan plastik PE tetapi berbeda nyata dengan kemasan lainnya (wrapping plastik dan koran) serta kontrol. Hal tersebut dapat terlihat dari Tabel 1 pada plastic PP dan PE hanya mengalami perubahan berat sebesar $5,84 \%$ dan 5 , $73 \%$, sedangkan pada kemasan wrapping plastic, koran dan kontrol terlihat perubahan bobot yang lebih signifikan.

Tabel 1. Nilai rata-rata susut bobot (\%) pakcoy hari ke-0 sampai ke-7 pada suhu dingin

\begin{tabular}{lcc}
\hline Suhu & Jenis Kemasan & Susut bobot (\%) \\
\hline \multirow{2}{*}{ Dingin } & Plastik PP & $5,84 \mathrm{a}$ \\
& Plastik PE & $5,73 \mathrm{a}$ \\
& Plastik Wraping & $10,14 \mathrm{~b}$ \\
& Kertas koran & $29,30 \mathrm{c}$ \\
& Kontrol (tanpa Kemasan) & $68,60 \mathrm{~d}$ \\
\hline
\end{tabular}

Keterangan : huruf yang sama pada kolam yang sama menunjukkan tidak ada perbedanyaan nyata pada uji lanjut dengan tingkat kepercayaan 95\%

Plastik PP dan PE lebih mampu menahan laju perubahan bobot karena kemasaan plastik PP dan PE memiliki ketebalan yang tinggi bila dibandingkan wrapping plastik maupun koran. Hal tersebut karena semakin tebal kemasan maka permeabilitasnya rendah, sehingga menghalangi transfer karbondioksida, oksigen dan uap air. Kemasan plastik memberikan perlindungan terhadap kehilangan air pada sayuran, sehingga sayuran yang dikemas masih terlihat segar [18]. Plastik sebagai kemasan juga merupakan alat yang baik untuk melindungi produk dari dehidrasi yang tinggi melalui kelembaban atmosfer sekitar produk dalam kemasan dan kemasan plastik cukup efektif mengurangi kehilangan air [8].

Perlakuan pada suhu dingin dengan kemasan dapat menjaga kesegaran danketegaran sayur sawi sehingga dapat

http://ejournal.urindo.ac.id/index.php/pertanian 


\section{Jurnal IImiah Respati}

mempanjang umur simpan sayur.
Pengemasan
menguran segar dapat (pengurangan berat) dengan demikian dapat mencegah terjadinya dehidrasi, terutama bila digunakan bahan penghalang kedap uap air. Hal ini dapat mempertahankan umur komoditas karena turunnya kandungan air akan menyebabkan kelayuan atau kisutnya bahan yang merupakan sebab hilangnya kesegaran, kenampakan tekstur, dan kemungkinan laku dijual [19]. Pengemasan sayuran segar harus diarahkan ke perlambatan proses respirasi, transpirasi, perubahan-perubahan kimiawi dan fisiologis, dan serangan mikroorganisme, tanpa mematikan sel-sel dan komoditas atau merusak mutunya [20].

\section{Kadar Air}

Salah atu indikator penting untuk mengontrol daya simpan suatu produk adalah kadar air. Beberapa produk perubahan kadar air mempunyai arti penting karena akan menyebabkan kelunakan atau keriput [21]. Kadar air dalam suatu produk perlu ditetapkan karena makin tinggi kadar air maka makin besar pula kemungkinan produk tersebut akan rusak, sehingga tidak tahan lama. Hasil pengamatan menunjukkan nilai kadar air pakcoy pada hari ke-0 adalah 93,84\% (Tabel 2). Pada Hari Ke-7, nilai kadar air cenderung menurun. $\mathrm{Hal}$ tersebut dikarenakan pakcoy setelah dipanen masih melangsungkan proses transpirasi. Komoditas hortikultura adalah merupakan produk hidup yang masih aktif melakukan aktifitas metabolismenya. Hal ini dicirikan dengan adanya proses respirasi dan tranporasi yang masih berjalan seperti halnya sebelum produk tersebut dipanen. Penurunan kadar air saat penyimpanan pada suhu rendah diakibatkan oleh terjadinya keseimbangan antara kadar air bahan dengan kelembaban yang ada disekitar ruang pendingin lebih rendah [22]. Air dalam suatu bahan pangan, termasuk jamur tiram putih merupakan komponen penting, sebab kadar air turut serta menentukan daya tahan dan acceptability bahan pangan tersebut [23].

Tabel 2. Nilai kadar (\%) air pakcoy hari ke-0 dan ke-7 pada suhu dingin

\begin{tabular}{llll}
\hline Suhu & Jenis Kemasan & \multicolumn{2}{c}{ Hari ke- } \\
\cline { 2 - 4 } & & 0 & 7 \\
\hline \multirow{2}{*}{ Plastik PP } & $93.84 a$ & $93.65 a$ \\
& Plastik PE & $93.84 a$ & $92.30 a$ \\
Dingin & Plastik Wraping & $93.84 a$ & $93.47 a$
\end{tabular}




$\begin{array}{cll}\text { Kertas koran } & 93.84 a & 91.87 a \\ \text { Kontrol (tanpa Kemasan) } & 93.84 a & 91.27 a\end{array}$

Keterangan : huruf yang sama pada kolam yang sama menunjukkan tidak ada perbedanyaan nyata pada uji lanjut dengan tingkat kepercayaan $95 \%$

Nilai penurunan kadar air terendah didapat pada pakcoy yang dikemas plastik PP yaitu sebesar 0,19\%. Plastik PP lebih mampu menghambat perpindahan air hal tersebut dikarenakan PP memiliki permeabilitas lebih rendah daripada PE kristalinitas lebih tinggi dibandingakan PE. Sehingga jumlah uap air yang dapat melewati kemasan plastik PE lebih besar dari kemasan plastik PP. Semakin sedikit uap air yang dapat menembus suatu bahan kemasan, keawetan bahan pangan yang dikemas dengan bahan kemasan tersebut akan semakin lama. PP memiliki sifat yang lebih kuat dan kokoh daripada PE. Selain itu, plastik jenis PE memiliki rantai cabang dalam molekulnya yang mencegah saling menumpukknya rantai tersebut dalam plastik sehingga kerapatannya menjadi lebih rendah. Suatu bahan yang memiliki kerapatan rendah mudah dilewati zat lain, seperti uap air karena adanya ronggarongga pada bahan tersebut akibat struktur kimia molekul penyusunnya yang kurang rapat [24]. Plastik jenis PP lebih sukar dilewati gas ataupun uap air daripada jenis PE karena sifatnya yang lebih keras dengan titik lunak yang lebih tinggi [25]. Makin tinggi kecepatan transmisi plastik maka makin tinggi pula

\author{
permeabilitasnya karena kecepatan \\ transmisi berbanding lurus dengan \\ permeabilitas.
}

\section{Total Plate Count (TPC)}

Parameter Total Plate Count (TPC) pada produk pangan sangat penting diperhatikan karena parameter ini erat hubungannya dengan keamanan produk pangan tersebut untuk dikonsumsi dan tingkat kerusakan produk pangan. Hal utama yang menjadi permasalahan dalam buah dan sayur segar adalah adalah keamanan mikrobiologi. Mikroba dapat terbawa secara alamiah yang potensial untuk bertahan hidup dan/atau yang berasal dari kontaminasi sepanjang proses pengolahan dan pengemasan. Indigenous mikroflora, yang terbawa secara normal dalam bahan, dapat mencapai $10^{5}$ hingga $10^{7} \mathrm{CFU}$ (Coloni Forming Unit), dimana 90\% diantaranya adalah bakteri gram-negatif berbentuk batang yang didominasi oleh: Pseudomonas, Enterobacter dan Erwinia, sedangkan pada penelitian lain pada wortel dan paprika hijau ditemukan juga bakteri yang bersifat psychrotrofik. Dalam hal terjadi fluktuasi temperatur akan ditemukan jenis bakteri asam laktat. Hasil pengamatan sayuran pakcoy pada hari ke-0 sampai ke-7 menunjukkan 
peningkatam kecuali pakcoy yang dikemas plastik PP (Tabel 3). Total mikroba pada pakcoy yang dikemas plastik PP dan PE lebih kecil dibandingkan kontrol dan kemasan lain. Hal tersebut membuktikan bahwa kemasan plastik mampu mencegah kontaminasi mikroba selama penyimpanan. Adanya kandungan TPC pada sayuran pakcoy disebabkan adanya kandungan mikroba awal yang berasal dari air penyiraman. Hal tersebut juga sesuai pendapat penelitian lain yang menyatakan bahwa sayuran yang baru dipanen sebenarnya telah ditumbuhi oleh berbagai macam mikroorganisme (mikroflora) dari yang tidak menyebabkan pembusukan sampai yang menyebabkan pembusukan [26]. Sayuran mengandung air dalam jumlah yang banyak yang sangat baik bagi pertumbuhan mikroorganisme. Mikroorganisme pembusuk dapat tumbuh bila kondisinya memungkinkan seperti adanya pelukaan-pelukaan, kondisi suhu dan kelembaban yang sesuai dan sebagainya. Mikroorganisme pembusuk pada sayuran merupakan faktor pembatas utama di dalam memperpanjang masa simpan sayuran. Mikroorganisme pembusuk yang menyebabkan susut pascapanen sayuran secara umum disebabkan oleh jamur dan bakteri.

Tabel 3. Nilai TPC (cfu/g) pakcoy hari ke-0 dan ke-7 pada suhu dingin.

\begin{tabular}{cccc}
\hline Suhu & Jenis Kemasan & \multicolumn{2}{c}{ Hari ke- } \\
\cline { 3 - 4 } & & 0 & 7 \\
\hline \multirow{3}{*}{ Dingin } & Plastik PP & $1,2 \times 10^{6} \mathrm{a}$ & $6,1 \times 10^{5} \mathrm{a}$ \\
& Plastik PE & $1,2 \times 10^{6} \mathrm{a}$ & $1,4 \times 10^{6} \mathrm{~b}$ \\
& Plastik Wraping & $1,2 \times 10^{6} \mathrm{a}$ & $6,4 \times 10^{6} \mathrm{e}$ \\
& Kertas koran & $1,2 \times 10^{6} \mathrm{a}$ & $2,8 \times 10^{6} \mathrm{~d}$ \\
& Kontrol (tanpa Kemasan) & $1,2 \times 10^{6} \mathrm{a}$ & $1,8 \times 10^{6} \mathrm{c}$
\end{tabular}

Keterangan : huruf yang sama pada kolam yang sama menunjukkan tidak ada perbedanyaan nyata pada uji lanjut dengan tingkat kepercayaan $95 \%$

Logam Berat ( $\mathrm{Pb}$ dan $\mathrm{Hg})$

Logam berat ialah unsur logam dengan berat molekul tinggi.Dalam kadar rendah logam berat pada umumnya sudah beracun bagi tumbuhan dan hewan, termasuk manusia. Logam berat yang sering mencemari ialah $\mathrm{Hg}, \mathrm{Cr}, \mathrm{Cd}, \mathrm{As}$ dan
$\mathrm{Pb}$. Logam timbal $(\mathrm{Pb})$ sangat berbahaya bagi manusia karena merupakan zat beracun yang tidak bisa dihancurkan atau diubah bentuknya. Zat ini bersifat stabil dan terakumulasi di dalam darah. Salah satu logam berat yang banyak mencemari air adalah timbal $(\mathrm{Pb})$. Karena hebatnya

http://ejournal.urindo.ac.id/index.php/pertanian 


\section{Jurnal IImiah Respati}

pencemaran $\mathrm{Pb}$ pada lingkungan, maka makanan yang dikonsumsi, air yang diminum dan udara yang dihirup kemungkinan besar telah terkontaminasi oleh $\mathrm{Pb}$, sehingga timbal disebut juga sebagai non essential trace element yang paling tinggi kadarnya dalam tubuh manusia. Tercemarnya air sungai oleh limbah pabrik yang mengandung $\mathrm{Pb}$ menyebabkan tanaman konsumsi yang tumbuh di daerah sungai menjadi tercemar oleh Pb.

Penelitian terhadap kemampuan beberapa tanaman untuk menyerap logam berat dari air yang tercemar. Ternyata pakcoy termasuk salah satu tanaman yang mudah menyerap logam berat dari media tumbuhnya [27]. Padahal pakcoy banyak dikonsumsi dan sering dijumpai tumbuh/ditanam di tanah-tanah kosong di sekitar daerah sungai dengan pengairan yang berasal dari sungai tersebut. Sampel yang digunakan adalah tanaman pakcoy yang ditanam secara aquaponik, sehingga lebih mudah dalam melakukan pemeliharaan dan pengontrolan. Kandungan logam berat yang terdeteksi pada sayuran pakcoy adalah $\mathrm{Pb}$, sedangkan $\mathrm{Hg}$ tidak terdeteksi. Kandungan awal $\mathrm{Pb}$ pada sayuran pakcoy adalah 1,20 ppm (Tabel 4). Adanya kandungan awal $\mathrm{Pb}$ pada pakcoy diduga berasal dari air siraman. Kandungan $\mathrm{Pb}$ pada air siraman sayuran pakcoy mencapai 0,216 ppm. Perlakuan jenis kemasan memberikan pengraruh nyata terhadap kandungan $\mathrm{Pb}$ pada hari ke-7. Kandungan logam berat $\mathrm{Pb}$ pakcoy mengalami peningkatan. Peningkatan tertinggi terjadi pada sayuran pakcoy yang dikemas kertas Koran.

Tabel 4. Nilai kandungan $\mathrm{Pb}(\mathrm{ppm})$ pakcoy hari ke-0 dan ke-7 pada suhu dingin.

\begin{tabular}{lccc}
\hline Suhu & Jenis Kemasan & \multicolumn{2}{c}{ Hari ke- } \\
\cline { 3 - 4 } & & 0 & 7 \\
\hline \multirow{3}{*}{ Dingin } & Plastik PP & $1,20 \mathrm{a}$ & $3,61 \mathrm{~d}$ \\
& Plastik PE & $1,20 \mathrm{a}$ & $2,98 \mathrm{c}$ \\
& Plastik Wraping & $1,20 \mathrm{a}$ & $2,63 \mathrm{a}$ \\
& Kertas koran & $1,20 \mathrm{a}$ & $4,02 \mathrm{e}$ \\
& Kontrol (tanpa Kemasan) & $1,20 \mathrm{a}$ & $2,77 \mathrm{~b}$
\end{tabular}

Keterangan : huruf yang sama pada kolam yang sama menunjukkan tidak ada perbedanyaan nyata pada uji lanjut dengan tingkat kepercayaan $95 \%$

SIMPULAN

Perbedaan penggunaan kemasan berpengaruh nyata trehadap susut bobot,
TPC dan kandungan logam berat $(\mathrm{Pb})$, sedangkan kadar air pada hari ke-7 tidak berbeda nyata. Penggunaan plastik PP 
lebih dapat mempertahankan mutu pakcoy sampai hari ke-7. Permeabilitas plastik polipropilen (PP) lebih kecil dibanding plastik polietilen dan kemasan lainnya sehingga uap air akan lebih sulit menembus plastik polipropilen daripada plastik polietilen. Semakin sedikit uap air yang dapat menembus suatu bahan kemasan, keawetan bahan pangan yang dikemas dengan bahan kemasan tersebut akan semakin lama.

\section{DAFTAR PUSTAKA}

[1] Yulia A.E., Murniati, Fatimah. 2011. Aplikasi Pupuk Organik pada tanaman Caisim Untuk Dua Kali Penanaman. J. Sagu. 10 (1) : 14-19.

[2] Iritani, G. 2012. Vegetable Gardening. Menanam Sayuran di Pekarangan Rumah. Yogyakarta (ID). Indonesia tera.

[3] Sugiyono. 2001. Fisiologi Pasca panen Hasil Tabaman Pangan. Fakultas Teknologi Pertanian. Institut Pertanian Bogor. Bogor.

[4] Kader, A.A. 2002. Postharvest Technology of Hortikultural Crops (3rd edition). USA. University of California, Davis.

[5] Walker, S. 2010. Postharvest Handling of Fresh Chiles. New Mexico State University. Mexico.

[6] Thompson, J.F. 2002. Storage System. P. 113-128. In A.A. Kader (ed), Postharvest Technology of Horticultural Crops (3rdEd.): The Regents of The University of California.

[7] Johansyah A, Prihastanti E, dan Kusdiyantini E. 2014. Pengaruh Plastik Pengemas Low Density Polyethylene (Ldpe), High Density Polyethylene (Hdpe)Dan Polipropilen (Pp)Terhadap Penundaan Kematangan Buah Tomat (Lycopersicon Esculentum.Mill). Buletin Anatomi Dan Fisiologivolume XXII, Nomor 1.

[8] Arianto,D.A., Supriyanto dan Laila K.M. 2013. Karakteristik jamur tiram (Plerotus ostreatus) selama penyimpanan dalam kemasan plastic polypropilen(pp). Agrotek No. 7: 6675.

[9] Mareta, T.D., dan S.A. Nur. 2011. Pengemasan Produk Sayuran dengan Bahan Kemasan Plastik pada Penyimpanan Suhu Ruang dan Suhu rendah. Jurnal Ilmu-IImu Pertanian, UGM, Vol. 7.(1) : Hal 26-40.

[10] Wills, R.H.H., Lee, T.H., Graham, D., Mc. Glasson,W.B. and E.G. Hall. 1998. Postharvest. An Introduction to the Physiology and Handling of fruits and Vegetables. New South Wales University Press Ltd., Kensington :105-107. 
[11] Chandra, D., Lee J.S., Choi H.J., and Kim J.G. 2018. Effects of Packaging on Shelf Life and Postharvest Qualities of Radish Roots during Storage at Low Temperature for an Extended Period.. Journal of Food Quality. Volume 2018, Article ID 3942071, 12 pages.

[12] Kirwan, M.J., and J.W. Strawbridge. 2003. Food Packaging Technology. Coles R., McDowell D., Kirwan M.J., editor.Canada (USA): Blackwell Publishing Ltd. hlm :174-227.

[13] Zainal \& Tawali AB 2004, 'Perubahan mutu buah anggur impor (Vitis vinivera) pada berbagai suhu penyimpanan', Jurnal Sains dan Teknologi, vol. 8, no. 4, hlm. 67-90.

[14] Husna, Izzul (2008) Pengaruh suhu penyimpanan dan pengemasan terhadap kesegaran brokoli (Brassica olercea L var. Royal green). Undergraduate thesis, Universitas Islam Negeri Maulana Malik Ibrahim.

[15] Imamah, N., Hasbullah, R., dan Nugroho, L.P.E. 2016 Model Arrhenius untuk Pendugaan Laju Respirasi Brokoli Terolah Minimal. Jurnal Keteknikan Pertanian. Vol. 4 No. 1, p 25-30. [21] Bartono. 2000. Pengantar Pengolahan Makanan. Perja. Jakarta.

[16] Calin, F., Nguyen the, C., Hilbert, G., dan Chambroy, Y. 1990. Modified atmospheres packaging of fresh "ready to use" grated carrots in polymeric film. Journal of Food Science, 55 : 1033-1038.

[17] Rachmawati R, Defiani MR, dan Suriani NL. 2009. Pengaruh suhu dan lama penyimpanan terhadap kandungan vitamin $\mathrm{C}$ pada cabai rawit putih (Capsicum frustescens). Jurnal Biologi XIII (2) : 36-40.

[18] Rochman. 2007 . Kajian Teknik Pengemasan Buah Pepaya Dan Semangka Terolah Minimal Selama Penyimpanan Dingin. Tesis. Fakultas Teknologi Pertanian Institut Pertanian Bogor. Bogor: 48.

[19] Nofriati, D dan Oelviani, R. .2015. Kajian Teknologi Pascapanen Sawi (Brassica juncea, L.) Dalam Upaya Mengurangi Kerusakan Dan Mengoptimalkan Hasil Pemanfaatan Pekarangan. BPTP Jambi.

[20] Muchtadi, T. R. 2000. Sayur-Sayuran Sumber Serat dan Antioksidan: MencegahPenyakit Degeneratif. Jurusan Teknologi Pangan dan Gizi. FATETA. IPB, Bogor.

[21] Bartono. 2000. Pengantar Pengolahan Makanan. Perja. Jakarta.

[22] Maulani, R.R. 2003. Perubahan Fisiologis Jamur Tiram (Pleurotus ostreatus) Segar Selama Penyimpanan Dalam Kemasan 
Jurnal IImiah Respati

Polietilen dan Polipropilen

Berperforasi. Thesis, IPB : Hal 5-35.

[23] Kadir, I. 2010. Pemanfaatan Iradiasi Untuk Memperpanjang Daya Simpan Jamur Tiram Putih (Pleurotus ostreatus) Kering. Jurnal Ilmiah Aplikasi Isotop dan Radiasi. Vol. 6. (1) : Hal 86-103

[24] Wilmer, A. Jenkins and James, P. Harrington. 1991. Packaging foods with Plastics. Technomic Publishing Company, Inc.
[25] Suyitno, 1990. Bahan-Bahan

Pengemas. PAU Pangan dan Gizi UGM, Yogyakarta.

[26] Utama, M.S. 2001. Penanganan pascapanen buah dan sayuran segar. Makalah "Forum Konsultasi Teknologi" Dinas Pertanian Tanaman Pangan Provinsi Bali.

[27] Seregeg, I.G. dan M. S. Saeni. 1995.

Media Litbangkes V18. 